\title{
Re-conceptualizing populism: Bringing a multifaceted concept within stricter borders
}

\author{
Hacia una reconceptuación del populismo: delimitando un concepto \\ multifacético en términos más estrictos
}

\author{
DAVIDE VITTORI \\ Libera Università Internazionale degli Studi Sociali Guido Carli (LUISS) \\ Cómo citar/Citation \\ Vittori, D. (2017). Re-conceptualizing populism: Bringing a multifaceted concept within stricter borders. \\ Revista Española de Ciencia Polífica, 44, 43-65. Doi: https://doi.org/10.21308/recp.44.02.
}

\begin{abstract}
The word populism has been associated to (very) different meanings in the last years. The "populist" label is still used to describe parties, leaders, movements, attitudes and political regimes, too. Moreover, the adjective "populist" is used in a normative fashion in the public debate to denigrate those movements or parties which contrast the mainstream views. The aim of this paper is twofold: on the one hand, I conduct a non-normative analysis to avoid a biased vision of the concept. On the other hand, I advocate the understanding of populism as a thin-centered ideology, according to which it is based on two necessary features, namely, (a) an anti-elite(s) mindset and (b) the criticism of representative politics.
\end{abstract}

Keywords: populism, comparative politics, concept analysis, thin-centered ideology.

\section{Resumen}

El término populismo ha sido asociado a significados muy diferentes en los últimos años. La etiqueta de populista se sigue utilizando para describir partidos, líderes, movimientos, actitudes y regímenes políticos. Además, el adjetivo populista se utiliza también con una inclinación normativa en el debate público para denigrar a esos movimientos o partidos que contrastan con las ideologías dominantes. Este artículo tienes dos objetivos principales: por un lado, desarrollo un análisis conceptual no normativo para evitar una visión sesgada del concepto. Por otra parte, abogo por una consideración del populismo como una ideología débil, según la cual se basa en dos características necesarias, a saber, (a) el anti-elitismo y (b) la crítica de la política representativa.

Palabras clave: populismo, política comparada, análisis conceptual, ideología débil. 


\section{INTRODUCTION}

The success of both anti-establishment and radical right parties in Western and Eastern Europe brought the attention of scholars, mass media and think-tanks on the populist phenomenon. The burgeoning academic literature on populism so far has ranged from the ideology and the organization of populist parties (among others, Betz and Johnson, 2004; Mudde, 2007; Stanley, 2008) to the attitudes of the electorate (Krouwel and Abts, 2007; Akkerman et al., 2013). It has also dealt with foreign policy (Schori-Liang, 2007; Veerbek et al., 2014), populist parties' participation in coalition governments (Akkerman, 2012; Akkerman and De Lange, 2012; Minkenberg, 2001; Heinisch, 2003; Fella y Ruzza, 2007) and their relationship with the democracy (Arditi, 2004; Meny and Surel, 2000; Canovan, 2002; Urbinati, 2013).

Soon after the 2014 European elections, the President of the European Parliament Martin Schultz (2015) defined populism as a threat for the stability of the whole European Union. In sum, populists were accused of oversimplifying the complex reality of the economic crisis and of campaigning for destructive reforms for Europe.

Populism, thus, was consciously transformed in an all-encompassing word aimed at denigrating or, at least, criticizing those movements or parties, which contrast the mainstream views. From another viewpoint, the approach that equates populism to a danger for democracy implies an inherently negative judgment on populism. In this regard, Müller (2016) defines populism as a degraded form of democracy. The normativity of such an approach, however, is misleading when dealing with this phenomenon (Mastropaolo, 2005), because it implies a disputable teleology -the pre-eminence of liberal values, whichever defined, over other forms of participation-. Moreover, the indistinctiveness of criticism of populism has led to mix it up with other political orientations, such as radicalism or, more likely, an exclusionary view against minorities. On a different perspective, the word populism has been associated with a distinctive "party family", the radical-right parties. In Europe, an a priori identification with this party family fostered a tendency toward an automatic identification of populism as a dangerous phenomenon for democracy.

The label "populism" is used also to describe fuzzy or charismatic leaders: Berlusconi (Taguieff, 1995), Haider (Betz, 1994; 2001), Le Pen (Shields, 2007), Grillo (Mosca, 2014; Tronconi, 2015) or Farage (Kelsey, 2015; Abedi and Lundberg, 2009) among others were portrayed as populist leaders in search of an unmediated relationship with the electorate. There is nothing new in this predisposition: since the growth of caudillismo in Latin-America, leadership was considered a sine qua non condition for populism. In an analogous way for the political parties, the terminology "populist leadership" is frequently adopted with an extremely negative "signified", in contrast with "responsible" and moderate leaderships.

The aim of this paper is twofold: relying on the literature on concept formation, I will define populism in a non-normative fashion to avoid a biased distortion of this concept; secondly, I will propose a minimal definition based on two necessary attributes (anti-elitism and the criticism of representative politics), seeking to balance the 
depth and breadth of the concept. Admittedly, a pure form of populism is more theoretical than real: similarly to liberal, conservative, social-democratic parties, movements and leaders that can share some ideological inclinations while differing in others, populists too, may have contrasting views on several policy issues. However, from a theoretical perspective it is crucial to identify a minimal definition that can provide the basis for consistent comparative studies, even if populism may be considered a more chameleonic "object" than other political phenomena (Taggart, 2000: 2).

The structure of the paper is as follows: the first section is devoted to theories on conceptual analysis. Subsequently, I revise the different approaches to populism in the literature. Several contributions in the last decades have helped disentangling the elusiveness of populist phenomenon. I divide these attempts into five main approaches. Although the selected definitions cannot be analysed solely through the category in which they are inserted since all of them contain different features that may be associated with other approaches, this method should provide clarity of the arguments developed here. Finally, I define populism as a thin-centered ideology whose core is represented by: (a) anti-elite vs. the "people" mindset, and (b) the criticism of representative politics.

\section{The basis for the concept analysis}

Despite the various and fruitful attempts to define crucial political science concepts, the literature on concept formation is largely underdeveloped: finding proper definitions for democracy, welfare or conflict still generates controversies among political scientists, even when an agreement on their operationalization can be found in the literature (Goertz, 2006; Gerring, 2012). Populism is not an exception to this trend. Furthermore, the word populism has been used by a broad range of scholars with disparate backgrounds and interests: political philosophy, sociology, political science etc. All these fields have different focuses and different ontological premises, which may lead to contrasting definition. While offering a comprehensive -although not exhaustive- overview of the different approaches, my main focus is on the concept of populism in political science. One of the most successful minimal definition has been provided by Mudde $(2004 ; 2007 ; 2010 ; 2013)$, whose work is now a point of reference for much of the literature on this topic. Starting from Mudde's work I try to re-conceptualize populism in an attempt to develop a more useful minimal definition.

Gerring (2012) identifies four steps in the process of concept reconstruction: the term; (b) the attributes that define the phenomenon; (c) the indicators that help to locate the concept in empirical space; and (d) the actual phenomena to be defined. Goertz (2006), on the other hand, proposes three levels of analysis: the basic level, the secondary level and the indicator/data level. Despite their differences, Gerring and Goertz agree on identifying two crucial aspects of concept analysis: the terminology and the delineation of attributes related to a concept. In Sartori's view (2009), giving a term its referent requires the re-construction of the meaning of the concept, since 
the meaning is the intermediation between the "world outside", i.e. the "objects", and the sequence of morphemes that forms the term (or the "signifier"). In Gerring's words " [c] oncepts strive to identify those things that are alike, grouping them together, and contrasting them to things that are different. Apples with apples, and oranges with oranges" (2012: 125).

In order to establish the referent to be adopted for each "object", the first step is to collect a set of representative definitions; secondly, the researcher has to inquire about the basic characteristics of the "object"; thirdly, he/she has to organize them, dividing between non-observable or at least-observable properties and extensional ones, which correspond to the very essence of a concept. Following Goertz (2006), once identified the basic level of a concept, i.e. its referent, the next step is the recognition of the secondary level, which comprises the constitutive dimensions of the concepts.

Since the purpose of this paper is to propose a minimal definition of populism -or a denotative definition in Sartori's terminology- the following paragraphs disentangle what has just been referred to as secondary level of the concept. In this regard, a minimum definition should possess the defining properties of the populism, while leaving aside the accompanying ones: the conceptual trade-off is between the depth and breadth of the concept. The definition should balance the so-called ladder of generality trade-off: on the one hand, if too many features (intension) are required for a political phenomenon to be considered "populist", then comparisons would be almost impossible and such a definition will be meaningless for social sciences. On the other hand, it is necessary to avoid any conceptual stretching (extension) including only the features that help to discriminate between what populism is and what populism is not. Avoiding ambiguity, "sorting out the membership of any given denotatum and [ ] deciding the cut-off point vis-à-vis marginal entities" is the essence of this work (Sartori, 2009: 112). Moreover, as Goertz highlights, the reconstruction of a concept should include a negative pole: if a minimal definition establishes what populism is, it must also specify what populism is not. Otherwise, the concept analysis would be indefinite and the minimal definition useless.

Following Gerring, I start my analysis of populism from a "conscientious semantic canvassing", which "begins with a representative sample of formal definitions and usage patterns for a chosen term, as drawn from relevant scientific fields" (2012: 132134). The following step will be the classification of attributes, an operation necessary to reduce the plenitude of meanings implied by a term. Although the literature on populism is massive, the identification of the most frequent attributes agreed upon by scholars allows for the reduction of "the definitional profusion of even the most complex concept into a relatively parsimonious table of attributes" (ibid.: 134).

\section{A semantic canvassing of the populist phenomenon}

Since the first relevant analysis on the issue, the academic literature has faced two main problems with the word populism: its ambiguity and the very different 
geographical and diachronic manifestations of populism, which encouraged its conceptual stretching. Several definitions have been provided, due to the impalpability of the term and the different manifestations of this phenomenon across time and space (Taggart, 1995; 2000; 2004).

In one of the first comprehensive studies on populism, Margaret Canovan (1981) found seven sub-categories of populism, four of which contain the label "populist": (1) farmers' radicalism, (2) peasant movements, (3) intellectual agrarian socialism, (4) populist dictatorship, (5) populist democracy, (6) reactionary populism and (7) politicians' populism. In his seminal work on the matter, Gino Germani (1978) referred to some hybrid formulas that appeared in Latin America in the 1960s and in 1970s, pertaining to a specific category labelled "national populism". Those categories include ideologies, movements and "qualities" of a political regime: from this point of view, populism is considered a qualification ascribed to different political phenomena and, for that reason, several accompanying attributes were attached to it.

When dealing with such an amorphous phenomenon there are two main questions to be addressed: firstly, how to categorize populism? And, secondly, how to set the boundaries of the definition?

As for the first problem, in their seminal work on populism Ionescu and Gellner concluded that it was difficult to define populism: "[a]s a doctrine or as a movement, it is elusive and protean. It bobs up everywhere, but in many and contradictory shapes" (1969: 4). The fact that populism is essentially considered as a context-dependent and chameleonic phenomenon (Taggart, 2000) fostered its elusiveness. In the introduction of their book, Ionescu and Gellner found that the worship of people is the main feature of populism; no other clearer definition was provided.

As for the problem of boundaries, Wiles (1969) detected twenty-four attributes of populism. The features ranged from "not being revolutionary and its opposition to class war, to its adoption of small co-operative as an economic ideal type, and its being religious, but opposed to the religious establishment" (Laclau, 2005a: 9). For the sake of clarity, the rest of the section is divided into five macro-areas in line with the approaches followed by the literature in the definition of populism.

\section{Populism as political illiberalism}

The most recent attempt to figure out a minimal definition of populism is that by Pappas $(2015 ; 2016)$, who focuses on the shortcomings of previous definitions and on the development of a minimal interpretation of "modern populism", that is "the occurrences of this phenomenon in post-WWII democracies around the world, which is qualitatively different from populisms in either predemocratic or nondemocratic political settings" (Pappas, 2015: 4, italics in the text). Recalling Zakaria's (1997) definition of "illiberal democracies" and trying to avoid ten methodological pitfalls (among them the conceptual stretching, the unclear negative pole, and the 
normative indeterminacy), Pappas defines populism as "democratic illiberalism" (2015: 10).

In essence, populism in polyarchies is interchangeable with non-liberal ideology. In a similar vein, for Urbinati populism "is a radical contestation of parliamentary politics and thus an alternative to representative democracy" (2014: 128). This way, populism is parasitical on representative democracy, since "it is not external to it and it does compete with it on the meaning and use of representation or the way of detecting, affirming, and managing the will of the people" (ibid.: 135, italics in the text).

The main strength of this approach is to specify the empirical universe of populism, namely, the criticism of political representation as conceived in polyarchies. Furthermore, it allows an operationalization of the term based on the liberal values incorporated by each parties, movement and leaders. Through discourse or policy-making analysis it would be possible to establish the degree of liberalism of the unit of analysis and "to use ordinal scales for indicating the rank order of populist phenomena" (Pappas, 2015: 16).

The minimal definition proposed by Pappas, however, needs to be carefully evaluated especially with regards to the methodological pitfalls that Pappas himself finds in other definition. In particular, the conceptual stretching of his definition leads to a paradoxical effect, in which every non-liberal party has to be considered populist. Every radical left, be them communist or post-communist parties, and radical right parties should fall within this category, too, while other self-labelled liberal or centrist parties that part of the literature identified as "populist" will not (Forza Italia in Italy for example, see Taguieff, 1995; Zaslove, 2008). If everything outside the mainstream liberal parties is "populist", then the label loses its relevancy. Despite the fact that the definition as "democratic illiberalism" distinguishes a clear negative pole, the nature of the negative pole is too wide and contradictory. On the one hand, it is unclear where "democratic liberal" ideology begins (or ends) within a party or a movement; on the other hand, liberalism as a "core" ideology already possesses its ideological opponents, such as communism, fascism and so on. Whether all these core ideologies can be considered as "populist" because of their non-liberal stance is highly disputable.

Moreover, to what kind of liberalism these alleged populist parties oppose to? According to Pappas, illiberalism is constituted by one main feature, i.e. the idea that political sovereignty pertains to the-people, and four sub-categories which are "fundamentally inimical to contemporary political liberalism": the willingness to create a political majority; the "over-soul" nature of the people; the perception of bipolarization of the world and the belief of holding the moral right (2015: 22). To what extent those attributes are inimical to liberalism is not clear, though.

2. Populism as a tool for political mobilization

Jansen defines populism as "any sustained, large-scale political project that mobilizes ordinarily marginalized social sectors into publicly visible and contentious 
political action, while articulating an anti-elite, nationalist rhetoric that valorises ordinary people" (2011: 82). In the same vein, Di Tella describes it as "[a] political movement which enjoys the support of the mass of the urban working class and/or peasantry but which does not result from the autonomous organizational power of either of these two sectors. It is also supported by non-working-class sectors upholding an anti-status quo ideology" (1965: 47).

Both definitions have an intriguing premise: populism takes place when at least part of the community mobilizes through political actions, be them either at party level or as a supporting "mass" for a political project. According to the authors, populism is more than a vague attitude of the single citizen/voter. However, other largescale political projects, whose aim is the emancipation of marginalized sectors of the society, shared -more or less successfully and with different political goals (e.g. socialism in its various forms or proto-fascist movements)- the tools for political mobilization. The latter approach is based on Di Tella's analysis of Latin-American populism in autocratic countries and it is based on the explanation of the political mobilization in support of the political leaders (caudillos). The difficulties in applying this definition in other geo-political contexts are related to the evolution of the labour forces and the mutated loci of organizational power. On the one hand, the dichotomies working class/non-working class and working class/peasantry are far less relevant to describe political mobilization, especially in what concern post-materialist values (Ingelhart, 1977). On the other hand, working or peasantry classes, if still relevant as political categories, have lost part of their organizational power, especially in highly institutionalized environment, such as Western Europe (or North America). It is not correct to argue that anti-status quo ideology is upheld only by non-working class, either. In fact, the study of the electorate of different so-called "populist" parties highlights a different perspective, in which populist parties receive support mainly from blue-collar worker, but also from self-employed and artisans (see Betz and Immerfall, 1998).

Jansen's attempt to describe populism as a mobilization tool is wider than Di Tella's. The argument here is focused on the organization of the marginalized social sectors involved and the use of a nationalist rhetoric (see section 4 for the analysis of this point).

If the discrimination between populist and non-populist is based on the political mobilization of the marginal sector, then anti-taxation movements with affluent supporters or anti status-quo parties with a mixed electorate (blue and white-collar workers) would fall outside the definition of populism. Leaving the problem of the nationalist rhetoric aside for a moment, the concept of marginalization tends to underestimate the possibility of anti-status quo "bourgeois", "liberal" or mainstream parties, which presumably speak (also) to citizens already involved in political life.

Secondly, according to Jansen, populist movements are large-scale or mass political projects; however, this assumption presupposes that all micro-scale or non-institutionalized parties should be considered as non-populist. Needless to say, some political parties that are now defined as "populist" started as small anti-establishment/anti-elite 
movements, whose projection was national only in the intentions (among other, FPO and Northern League, but also the Progress Parties in Norway or the National Front in France). As far as electoral success is concerned, it is self-evident that "populism" cannot be defined by the share of votes that a party or a movement obtain in the elections.

3. Populism as a leader-led movement

The third approach to populism is based on the centrality of the leadership and the unmediated relationship with the "people". For example, Roberts argues that populism represents a "political mobilization of mass constituencies by personalistic leaders who challenge established elites" (2006: 127) while, according to Weyland populism is a "political strategy through which a personalistic leader seeks or exercises government power based on direct, unmediated, uninstitutionalized support from large numbers of mostly unorganized followers" (2001: 14). And according to Urbinati "while the epistemic interpretation of democracy is headless, populism can hardly exist without a politics of personality; while the former aims at erasing ideology and all forms of sedimentation of opinions, the latter lives out of a strong ideological rhetoric" (2014: 131).

As for the scale of the project, I have already underlined that mass constituencies are not a prerequisite for populism. The most relevant characteristic of the above definitions lays in their focus on the leader as convenor of populist attitudes. As Mudde and Kaltwasser explain in this regard "an elective affinity between populism and a strong leader seems to exist. However, the former can exist without the latter" (2014: 383). The diversity in the internal organization of European populist parties cannot lead to the equation between charismatically-led parties and populist parties. The synonymy of the two terms is misplaced in that case. Urbinati (2014) proposes a distinction between all leaderless movements -such as the Occupy movements in the United States, the Indignados in Spain or the Kínima Aganaktisménon-Politón in Greecewhich are considered popular manifestation of the dissatisfaction toward some aspect of the contemporary capitalist world, and the leader-led movements which are populist because of the presence of a leader. However, the repertories of contention of the former crucial populist features such as the political mobilization and the criticism about the élite (see sections 2 and 5).

Thus, the extensive selectiveness of a definition in which leaders are considered to be essential allows the overtly discriminating exclusion of all leaderless movements. The adjective "personalistic" is also troublesome: while Latin-American parties and movements in autocratic contexts show a high degree of personalismo, in which leaders bounded their political destiny to the organizations that they founded (De la Torre, 2010), in other (European) cases, populist leaders emerged from within the party (among others, Matteo Salvini in the Northern League, Marine Le Pen in the National Front) after relevant charismatic leaderships. Other deviant cases entail political 
entrepreneurs with populist attitudes, who were successfully (in electoral terms) replaced by other leaders after a transition phase (among others, the Freedom Party of Austria and the Progress Party in Denmark). Admittedly, other parties faced resounding failures after the fall of the leadership (L'Uomo Qualunque in Italy or the Pim Fortuyn List in the Netherlands), but this is not the rule: the institutionalization in any political party is caused by internal and external factors and the change of the leadership may be just one of them.

Although strong leaders may be the "key for mobilizing the people and (re)founding the political organization specialized in fostering a direct an unmediated relationship with the electorate" (Mudde and Kaltwasser, 2014:387), leadership in itself cannot be considered a defining feature of the populist phenomenon, unless all leaderless movements (such as Occupy Wall Street, the Indignados movements in Spain and Greece and the Popolo Viola, in Italy) are a priori treated as non-populist ones.

\section{Populism as a communicative/discursive tool}

The analysis of populism as a communicative style emphasizes the way prominent members of a political community, from the party secretary to opinion leaders, use anti-elite rhetoric in order to gain support from the audience. Jagers and Walgrave consider populismas a political communication style by political actors that refers to the people (2007: 322). These political actors can be politicians and political parties, but also movement leaders, interest group representatives and journalists.

To some extent, this is the definition that Canovan $(1981$; 1984) found more convincing in her seminal works; in her own words, the only feature that populists have in common "is a rhetorical style which relies heavily upon appeals to the people" (Canovan 1984: 313). One important implication of this definition is its a-normativity: whoever speak about "people" and for the "people" in general should be regarded as populist; for, "[b]y referring to the people, a political actor claims that he or she cares about the people's concerns [...]. The implicit populist's motto is: 'I listen to you because I talk about you.'” (Jagers and Walgrave, 2007: 323). Furthermore, another merit is the possibility of a straightforward operationalization of the definition. If populism is a rhetoric style, the discourse analysis based on the appeal to the people would be a solid starting basis. However, a key problem with this definition is the overstretching of the concept. The "thin" definition chosen by Jagers and Walgrave implies that populism is just a communicative strategy that anyone can use in any given moment simply when referring to the "people". There is not, in the definition, any references to the "quality" of the address to the people. From this perspective, for example, Lincoln's Gettysburg address -the government of the people, by the people, for the people- should be considered the masterpiece of populism. Thus, the vagueness of the definition makes the boundaries of the concept unclear. The appeal to the "people" and all the synonyms related to this word does not configure per se a populist phenomenon. 
Similarly to Jagers and Walgrave's definition, De la Torre sees populism as a rhetoric that construct politics as the moral and ethical struggle between el pueblo and the oligarchy. Populist discourse transumates politics into a struggle for moral values without accepting compromise or dialogue with the opponent (2010: 4). Here, the political style is more than a mere reference to the people and it is focused on the contraposition between the people (el pueblo) and the elite(s) (the oligarchy). This way, the previous indefiniteness of the concept of populism is limited to a confrontational discourse. Nonetheless, in this definition populists are those who refuse a compromise with the opponents within or outside a parliamentary system; yet, from a European perspective there are plenty examples of "populist" parties that participated in coalition governments both as a majority and junior partners (Forza Italia and Northern League in Italy, Progress Party in Norway, Freedom Party of Austria, Alliance for the Future of Austria, Fidesz in Hungary, the Pim Fortuyn List in the Netherlands) or condoning the government, without being part of the government (Party for Freedom in the Netherlands and the Danish People's Party in Denmark). These examples suggest that populists may be prone to compromise when the circumstances allow them to participate in government. Even when improving the discriminative power of the previous definition, the exclusion from the analysis of those parties that participated in coalition government would be too selective both for European and Latin-American contexts.

Another definition, slightly different but somehow complementary to the previous one, was proposed by Ernesto Laclau (2005a) and Hawkins (2009). In Hawkins' words, populism is a "Manichaean discourse because it assigns a moral dimension to everything, no matter how technical, and interprets it as part of a cosmic struggle between good and evil" (2009: 1043). Using a Gramscian framework of analysis, Laclau defines populism looking at the discursive practice rather than its content. Populism starts when people with same political demands pour an empty signifier (a political instance) against a hegemonic practice. Populism is set against the logic of administration, which splits demands that "populism" bands together giving a consistent "signified" to an empty "signifier" (see also Panizza, 2005). Thus, "[i]f this approach is correct, we could say that a movement is not populist because in its politics or ideology it presents actual contents identifiable as populistic, but because it shows a particular logic of articulation of those contents -whatever those contents are" Laclau (2005b: 33)-.

From an analytical point of view, the puzzle is how to set boundaries to the concept. Indeed, populism as a content-unbounded concept poses a problem of ambiguity; accompanying properties and non- or at-least observable properties are mixed with defining properties in this approach, leaving a subjective interpretation of the way in which the logic of articulation is disentangled within the discursive practice. Following Mudde and Kaltwasser (2012), I contend that limiting the analysis to the Manichean interpretation of the reality stretches the definition beyond its theoretical limits, since it may be applied to other core or thin-centred ideologies which incorporate a binary distinction between the "Us" -namely the people in the case of 
populism, but also the Nation in a nationalist view or the proletariat in a communist ideology- and the "Others", who are the opponents of the "Us-group".

\section{Populism as an ideology}

The fifth group of definitions considers populism as an ideology. Ideology, according to Jost et al. (2009) an ideology "reflect[s] both genuine (and even highly accurate) attempts to understand, interpret, and organize information about the political world as well as conscious or unconscious tendencies to rationalize the way things are or, alternatively, the desire for them to be different" (ibid.: 310). Thus, ideologies "enable meaningful political worlds to be constructed, as well as translating the multiplicity of potential conceptual meaning into the singularity of a political decision" (Freeden, 1998: 749). As a more or less structured set of beliefs, populism rationalizes in its own way the political world through the anti-elite lenses. Anti-political status quo and the appeal to a homogeneous political community, moreover, are the starting points from where populists propose a different political world, in which the powerful elite(s) are ousted from key governing office. Albertazzi and McDonnell, for example, define populism as "an ideology which pits a virtuous and homogeneous people against a set of elites and dangerous 'others' who are together depicted as depriving (or attempting to deprive) the sovereign people of their rights, values, prosperity, identity and voice" (2008: 14).

One possible shortcoming of this interpretation is that the various forms of populism do not exhibit a consistent and all-e ncompassing view of a given political context. Rather, as the supporters of the discursive typology would argue, populism is shaped and re-shaped by rhetorical and ideological tools, based on a Manichean distinction of the "people" and the "elite(s)". Populism, thus, is more flexible vis-à-vis other more structured ideologies.

Canovan underlines that "it may be argued that there can be such a thing as a populist ideology. But attempts to define populism in terms of any such ideology fail, because in another context the anti-elitist mobilization concerned may be reacting to a coherent ideological environment" (1999: 4). And he adds that "[s]o-called 'populists' are to be found on the right, left and centre of the political spectrum, and almost any generalization about them can be defeated by a counter-example" (1984: 2). This criticism may be sustained only if populism is analysed as any other classical ideologies.

However, ideologies may be either "core" or "thin-centred". Thin-centred ideologies present structural inability to offer complex ranges of argument because many chains of ideas [...] are simply absent. [...] A thin-centred-ideology is hence limited in ideational ambitions and scope" (Freeden, 1998: 750). Thin-centrism can be equated to a cross-cutting principle that influences the way other issues, which are not the core arguments of the thin-centred ideology, are framed. Freeden found this feature in nationalist ideology, but Mudde (2004) applied the same interpretation to populism. More recently, Freeden has challenged this. In his view, populism "not only falls short 
of comprehensiveness but short of nuanced specificity in what it does offer. Vagueness and indeterminacy may be good vote-catchers, but the result is at best a phantom ideology" (Freeden, 2017: 10). Thus, it cannot be considered an ideology unless it refers to contrasting trends: "(1) when it serves as a convenient catch-all marker of radical popular demands that clamour for legitimation, and (2) when it is used to denounce particular brands of right-wing xenophobia" (ibid.: 11). Although populism is more indeterminate with respect to "what it does offer" than other thin-centred ideology, populists in the interpretation I provide here may articulate political programs, relying on eminently ideological concepts anti-elitism and the criticism to representative democracy. Freeden seems to undervalue that the use of referenda, for example, is a good example of policy-making critical to representative politics. Even if the content of referenda may vary (according to the core ideologies incorporated by populists), the critical frame of both the forms of political intermediation and the representatives of the intermediation is a peculiar ideological trait.

Thus, the presence of a populist ideology in different political context and in different political actors (parties, movements and leaders) is consistent with the loosely-based definition of ideology that is provided here. Hence a more suitable definition of populism may be: a thin-centered ideology that considers society to be ultimately separated into two homogenous and antagonistic groups, 'the pure people' versus 'the corrupt elite,' and which argues that politics should be an expression of the volonté générale (general will) of the people" (Mudde, 2004: 543, italics in the text).

The main pitfall of this definition is the dyad "pure"/ "corrupt". Certainly, there may be a strong anti-corruption stance in most populist parties; but this does not necessarily mean that the antagonism proposed by populists is between the people and a corrupt elite.

The same inference may be drawn from the adjective "pure". A positive evaluation of the communities of interest is a conditio sine qua non during electoral campaigns of any type. A counter-argument would be that purity refers to something or someone uncontaminated by unnecessary or "unclean" substances; as a consequence, "pure people" are not mixed with elites. The "people" who populists address, however, is the same "people" that may have previously vote for "pro-elite" party or have been contaminated by elite(s)-driven parties. The purity of the "people", if and when recalled by populists, looks like a rhetoric tool used to clearly distinguish "us" from the "other" in order to degrade the minorities. "Purity", in conclusion, may refer to other thin-centred ideologies (e.g. nationalism) and it can be considered a step further with respect to a minimal definition.

\section{THE CLASSIFICATION OF ATTRIBUTES}

The minimal definitions provided so far have proved to be only partially satisfactory for the reconstruction of the concept of populism. Therefore, I move to the classification of traits the literature attributes to populism. Starting from those 
identified in the previous minimal definitions and adding other possible ones, I enlist ten characteristics which have been considered necessary for populism to different degrees. Out of twelve features commonly associated to populism, Rooduijn extracts four minimal ones: (1) emphasis on the central position of the people; (2) criticism against the elite; (3) conception of the people as a homogeneous entity and (4) conviction of living in a period of serious crisis (2014: 573). Similarly, Taggart (2000: 2) identifies six crucial populist characteristics: (a) hostility to representative politics; (b) idealization of the "heartland"; (c) absence of core values; (d) a reaction to the crisis; (e) populism as containing fundamental dilemmas that makes it self-limiting; and (f) a context-dependent phenomenon. According to Taguieff, the national-populist ideal-type (the National Front in France) -comprises five features: (I) the personal appeal to the people, (II) the appeal to a classless people, (III) the direct appeal to the authentic, sane, simple and honest people, (IV) the call for purification or redemptive rupture and (V) the discrimination among individuals in terms of ethnic origin or cultural characteristics (1995: 27-32)-. Combining the three sets of features it is plausible to identify ten basic features: (1) Populism as an ideology lacking core value; (2) anti-elitism; (3) the hostility to representative politics; (4) a mobilization against the political status-quo (rupture); (5) the personal appeal to the people; (6) the homogeneity of the people; (7) the ethnic and cultural discrimination; (8) the idealization of the "heartland"; (9) a sense of perceived crisis; and (10) a context dependent and self-limiting phenomenon.

As explained in the previous paragraphs, among the different theoretical interpretations of populism, the one related to ideology proves to be the most robust. However, this theoretical foundation cannot be defined as a basic feature of populism; rather it is an assumption from which the reconstruction of the concept can be conducted fruitfully. As it will be explained in the following paragraph, the necessary attributes are identified in anti-elitism and the resulting opposition between the élite and the people (attribute 2) and (attribute 3) the criticism toward representative politics.

In what follows, I will focus on the remaining features, explaining why they should be excluded from the minimal definition. In the previous sections I have already discussed attributes (4) political mobilization and (5) the necessity of a strong or charismatic leadership. There seems to be an agreement among scholars on the essential distinction between the "homogenous" people and the "others". I do not challenge the centrality of people in populist ideology; however, I contend that the concept of "homogenous" people is normatively biased as it is related to a distinct conception of people typical of radical-right parties. Unless the minimal definition of populism refers only to this party family, the attribute of the homogeneity must be left aside or, at least, be considered as an accompanying feature of one of the different forms populism, i.e. the "exclusionary" populism.

As for attribute (6), the homogeneity of the people, Meny and Surel (2000) describe three usages of the term people: sovereign-people, class-people and nation-people. None 
of them can be classified as specific of populism, since all of them correspond to other ideologies (nationalism, socialism) or, at least, to the way state-building has evolved in history. As explained by Mudde and Kaltwasser (2013) populism is both "exclusionary" and "inclusionary", depending on the core ideologies it relies on. In these authors' view, populists share "the way in which populist actors define who belongs to 'the people' visa'-vis 'the elite", but, on the other hand, "the ideological features that are attached to the particular populist ideology of the actors" (ibid: 148) range from radical-left to radical-right.

Paradoxically, other core ideologies are indispensable to define who the people are, thus a "populist-people" cannot exist per se. For that reason, reaching a common definition of populism based on a stable definition of the concept people (see Meny and Surel, 2000) ) seems impractical. Sovereignty, class and nation comprise very different "we" and, mostly, very different "others". These three concepts may be useful complimentary attributes to populism, but their insertion in a minimal definition is overtly discriminative. Populist do refer to "the people" or "the majority of the people", but this appeal is aimed at clearly distinguish between the elite(s) and the non-elitists, rather than to proclaim the homogeneity or the purity of the people.

Moving to attributes (7) and (8), when populists refer to (7) the purity of a particular group and to its glorious past (locally, nationally or class-based) they adopt other relevant ideologies to justify the exclusion of these "others" (nationalism, federalism or regionalism, socialism, but also liberalism, when framed as the distinction between liberal values and non-democratic groups). Whichever (8) the framing of the heartland, the discrimination between what is inside and the out-group relies on the core ideologies adopted by the in-group. Albeit there may be a correlation between populism and "crisis" (Kriesi and Pappas, 2015), (9) the sense of "crisis" that populists perceive in any political context should be regarded more as a rhetoric tool used also by other non-populist parties than a pre-condition for the populism to emerge.

Attribute (10) -self-limiting and context-dependency phenomenon- is also unnecessary for the scope of a minimal definition. The aim of a minimal definition is to widen the extension of the phenomenon, while setting precise boundaries to avoid the overstretching of the concept. Context-dependency, rather, makes analytically useless a minimal definition, since it would be very problematic to find common and recurrent populist habits. The interpretation as a self-limiting phenomenon is based on the assumption that populist parties, movements or leader cannot get institutionalized as a result of their confrontation with the complexity of the decision-making within the representative institutions. Focusing on the radical right party family, whether we look at populism as "pathological normalcy" (Mudde, 2010) or a normal pathology (Betz, 1994), the (electoral) stability of populist right wing parties has been extensively recognized in the literature (Ivarsflaten, 2008; Mudde, 2013 and Rooduijn, 2015), not only for the growing electoral importance of parties labelled as "populists", but also because of their active participation in coalition government (Akkerman, 2012; Akkerman and De Lange, 2012). 


\section{TOWARD A MINIMAL DEFINITION}

Bearing in mind the previous annotations I define populism as a thin-centred ideology whose core is represented by two necessary features: (a) anti-elite(s) mindset, and (b) criticism of representative politics. I explained in the previous section the choice for the thin-centred ideology. Additional comments are required regarding the above features (a) and (b).

The anti-establishment attitude is intentionally left out of point (a), because an anti-establishment stance cannot be equated to anti-elitism. Although populists would never consider themselves as part of the political establishment, when (and if) overcoming the process of institutionalization within a given political system they become part of the establishment. Bearing in mind the abovementioned resilience of the so-called populist parties in Europe, they should be expected to become part of the establishment in the medium term. Treating them as part of the establishment, however, is not in contradiction with anti-elite discourse. Anti-elitism is boarder in its meaning and it refers to the antagonism towards the "most powerful" national or supranational economic, political, cultural elites that decide the destiny of the people. Thin-idealistic principles may consistently remain stable over the time in populist parties/movements.

However, an anti-elite(s) attitude is a necessary but not sufficient condition for the populist ideology to be fully unfolded; otherwise, anti-elitism should be considered synonym for populism in violation of the anti-synonymy principle outlined by Sartori in rules $3 \mathrm{a}$ and $3 \mathrm{~b}(2009: 114)^{1}$.

Rather, a more exhaustive definition of populism should foresee another attribute, i.e. the criticism of representative politics. I prefer the term 'criticism' to 'hostility' because the former has a broader meaning, which comprises both the principles hostility toward political representation per se and a more moderate stance against the way political representation is organized in a given time, without advocating for its replacement tout court. The anti-elite(s) mindset is related to a political discourse, whose aspiration is to replace the dominant "minority" (the elite which may belong to different areas, ranging from economics to politics and from the judiciary power to culture and media). This definition is neutral about the "who", i.e. the political entrepreneurs that incorporate populism within their own ideologies. Insofar as it may appear paradoxi$\mathrm{cal}$, anti-elitism is not precluded to elitist outsiders, especially when it is related to the criticism of a peculiar elite, from which the outsiders are excluded. For instance, this explains why tycoons or other members of a "privilieged" class may handle a consistent populist ideology. Anti-elitism, in this case cannot be regarded as a synonym of

1. Following Sartori's guide for concept analysis, rule 3a states that "[a]waiting contrary proof, no word should be used as a synonym for other word" (2009: 114). According to rule 3b, "[w]ith respect to stipulating synonymies, the burden of proof is reversed: what requires demonstration is that by attributing meanings to different words we create a distinction of no consequence" (Sartori, 2009: 114). 
anti-pluralism. Nor all populists are anti-pluralist per se. Although populists may be anti-pluralist (Müller, 2016; Pappas, 2015; 2016), i.e. rejecting the concept of political pluralism and political representativeness, both concepts are ontologically different and there is no automatism between them.

The criticism of political representation may take different forms. On the one hand, it may be directed against the classical horizontal left-and-right division (Bobbio, 1994). Populists challenge the classical horizontal axis of the political division (left and right), focusing instead on the vertical axis, which divides between the powerful few and the people. Albeit parties which incorporate a populist ideology may be placed in the left or the right spectrum of the spectrum, populism in itself is neutral to this distinction. Other core ideologies, in this regard, can justify the insertion of a party in the left/right spectrum: communism for radical-left parties, social-democracy for centre-left parties, liberalism for centrist parties, conservatism for centre-right parties etc. In his comparative work on populism, Pappas concludes that there is not a single populist constituency whether within a specific country or across countries; "individuals belonging in the informal sector of economy in countries like Peru or Venezuela may be attracted to populist leaders in similar ways as French industrial workers, Greek farmers, or Dutch upper-middle class strata" (2012: 15).

Moreover, populists reject a Weberian professionalization of politics. Albeit being frequently undetermined, one of the most salient issue in the populist discourse is the radical transformation of both the political class and, particularly, the parties' bureaucracy, the so-called Party in Central Office.

The criticism of elitism both in politics and political representation, which is crucial for populism to become a thin-centred ideology, has a policy-making aspect in that it advocates people's participation in the decision-making process. Here, participation entails the (promises of) involvement in the decision-making both at governmental level and within the party or movement through the instrument of referendum, portrayed by populists as the main tool to "let the people" decide over their destiny without the influence of the elite. However, referenda are not a populist instrument per se, as the experience of referenda in Switzerland show. Still, when a party or movement advocates a referendum, coupling its campaign with an anti-elitist discourse and a manifest criticism of political representation, it can be argued that this party or movement has incorporated the populist thin-centred ideology.

This definition entails some relevant implications. Firstly, it is non-normative since judgements about the populist threat to democracy (Rosanvallion, 2008) or its troublesome relationship with representative democracy (Taggart, 2004; Urbinati, 2013 ; 2014) are absent. Secondly, although a positive correlation between the presence of a "mediatized" (Mazzoleni and Schultz, 1999; Mazzoleni, 2003) political entrepreneur and populism may be detected, it is not a necessary condition per se. A strong leadership may be a facilitating factor to convey a populist ideology; however, the presence of leaderless populist parties cannot be excluded a priori.

Thirdly, and in disagreement with Freeden (2017), it highlights the importance of the thin-centred ideology concept. Populism can be found in parties, movements or 
leaders with different core ideologies: right-wing parties (see among a vast literature, Taggart, 1995; Mudde, 2007) left-wing parties (Stavrakakis and Katsambekis, 2014; Weyland, 2013; Roodujin and Akkerman, 2015) and even liberals and greens (Zaslove, 2008; Müller-Rommel, 1998).

Finally, this definition tries to balance the depth and breadth of populism. Following the literature on concept formation, I have focused primarily on the necessary attributes of populism, leaving aside all accompanying characteristics. The result of this process combines two attributes -anti-elitism and the criticism of representative politics- which represent the populist core. Neither anti-elitism per se nor the criticism of representative politics taken separately can be considered as populist -it would be a breach of the Sartorian rule on synonymy-. Rather, the combination of both aspects is a more or less conscious attempt to organize information about the political world, through the peculiar distinction of two groups, i.e. the élite and the political representatives on the one hand and what the populists define as the "people" on the other.

\section{CONCLUSION}

In this paper, I firstly focused my attention on the definitions of populism provided by the academic literature. I identified five main categories that approach the populist phenomenon in five different ways: (1) populism as political illiberalism, (2) populism as a political mobilization tool, (3) populism as a leader-led movement, (4) populism as a discursive/rhetoric tool and (5) populism as an ideology; and I discussed both the strengths and possible pitfalls of those approaches. Combining this review with other minimal attributes of populism identified by the literature, I developed a minimal definition trying to balance the need for a suitable extension so to cover a wide range of political phenomena and the need to set precise boundaries between the positive pole (what populism is) and the negative pole (what populism is not). Following the ideological approach, I defined populism as a thin-centred ideology that incorporates two necessary attributes, anti-elitism and the criticism of political representation. Finally, I highlighted some relevant implications of this such as the non-normative nature of populism, its attachment to other core or thin-centred ideologies and its balance between the breadth and depth of the concept.

Further research is needed to streamlining the definition of populism and operationalizing it; moreover, the literature will also benefit from further analysis of the suitability of adjectives attributed only to populists, such as "media-populist", "tele-populist" or "vague populism", etc.

\section{References}

Abedi, Amir and Thomas L. Lundberg. 2009. "Doomed to Failure? UKIP and the

Organisational Challenges Facing Right-Wing Populist Anti-Political Establishment 
Parties", Parliamentary Affairs, 62 (1): 72-87. Available at: https://doi.org/10.1093/ $\mathrm{pa} / \mathrm{gsn} 036$.

Akkerman, Tjitske. 2012. "Comparing Radical Right Parties in Government: Immigration and Integration Policies in Nine Countries (1996-2010)", West European Politics, 53 (3): 511-529. Available at: https://doi.org/10.1080/01402382.2012.6 65738.

Akkerman, Tjitske and Sarah L. De Lange. 2012. "Radical Right Parties in Office: Incumbency Records and the Electoral Cost of Governing", Government and Opposition, 47 (4): 574-596. Available at: https://doi.org/10.1111/ j.1477-7053.2012.01375.x.

Akkerman, Tjitske, Cas Mudde and Andrej Zaslove. 2013. "How Populist Are the People? Measuring Populist Attitudes in Voters", Comparative Political Studies, 47 (9): 1324-1353. Available at: https://doi.org/10.1177/0010414013512600.

Albertazzi, Daniele and Duncan McDonnell. 2008. "Introduction", in Daniele Albertazzi and Duncan McDonnell (eds.), Twenty-First Century Populism the Spectre of Western European Democracy. New York: Palgrave MacMillian. Available at: https://doi.org/10.1057/9780230592100_1.

Arditi, Benjamin. 2004. "Populism as a Spectre of Democracy: A Response to Canovan", Political Studies, 52 (1): 135-143. Available at: https://doi.org/ 10.1111/j.1467-9248.2004.00468.x.

Betz, Hans-Georg. 1994. Radical Right-Wing Populism in Western Europe. Basingstoke: Macmillan. Available at: https://doi.org/10.1007/978-1-349-23547-6.

Betz, Hans-Georg. 2001. "Exclusionary Populism in Austria, Italy, and Switzerland", International Journal, 56 (3): 393-420. Available at: https://doi.org/10.1177/ 002070200105600302.

Betz, Hans-Georg and Carol Johnson. 2004. "Against the Current. Stemming the Tide: the Nostalgic Ideology of the Contemporary Radical Populist Right", Journal of Political Ideologies, 9 (3): 311-327. Available at: https://doi.org/10.1080/13 56931042000263546.

Betz, Hans-Georg and Stefan Immerfall (eds.). 1998. The New Politics of the Right: Neo-Populist Parties and Movements in Established Democracies. London: Macmillan.

Canovan, Margaret. 1981. Populism. New York: Harcourt Brace Jovanovich.

Canovan, Margaret. 1984. "People', Politicians and Populism", Government and Opposition, 19 (3): 312-327. Available at: https://doi.org/10.1111/ j.1477-7053.1984.tb01048.x.

Canovan, Margaret. 1999. "Trust the People! Populism and the Two Faces of Democracy", Political Studies, 47 (1): 1-16. Available at: https://doi.org/10.1111/ 1467-9248.00184.

Canovan, Margaret. 2002. "Taking Politics to the People: Populism as the Ideology of Democracy", in Yves Mény and Yves Surel (eds.), Democracies and the Populist Challenge. London: Palgrave Mcmillian. Available at: https://doi.org/10.1057/ 9781403920072_2. 
De la Torre, Carlos. 2010. Populist Seduction in Latin America (2nd ed.). Ohio: Ohio University Press.

Di Tella, Torquato S. 1965. "Populism and Reform in Latin America", in Claudio Veliz (ed.), Obstacles to Change in Latin America. Cambridge: Cambridge University Press.

Fella, Stefano y Carlo Ruzza. 2007. "The National Alliance and Northern League in Italy: Rivals in Power, Enemies in Defeat”, in Pascal Poirier y Pascal Delwit (eds.), Identités, Politiques, Sociétés, Espaces: Extrême droite et pouvoir en Europe. Brussels: Université libre de Bruxelles.

Freeden, Michael. 1998. "Is Nationalism a Distinct Ideology?”, Political Studies, 46 (4): 748-765. Available at: https://doi.org/10.1111/1467-9248.00165.

Freeden, Michael. 2017. "After the Brexit Referendum: Revisiting Populism as an Ideology”, Journal of Political Ideologies, 22 (1): 1-11. Available at: https://doi.org /10.1080/13569317.2016.1260813.

Germani, Gino. 1978. Authoritarianism, fascism, and national populism. New Brunswick, New Jersey: Transaction Publishers.

Gerring, John. 2012. Social Science Methodology. A Unified Framework (2nd ed.). Cambridge: Cambridge University Press.

Goertz, Gary. 2006. Social Science Concepts. Princeton: Princeton University Press.

Hawkins, Kirk A. 2009. "Is Chavez Populist? Measuring Populist Discourse in Comparative Perspective”, Comparative Political Studies, 42 (8): 1040-1067. Available at: https://doi.org/10.1177/0010414009331721.

Heinisch, Reinhard C. 2003. "Success in Opposition. Failure in Government: Explaining the Performance of Right-wing Populist Parties in Public Office", West European Politics, 26 (3): 91-130. Available at: https://doi.org/10.1080/0140238 0312331280608.

Inglehart, Ronald. 1977. The Silent Revolution. Princeton: Princeton University Press. Ionescu, Ghita and Ernest Gellner (eds.). 1969. Populism: Its Meaning and National Characteristics. New York: Macmillan.

Ivarsflaten, Elisabeth. 2008. "What Unites Right-Wing Populists in Western Europe? Re-Examining Grievance Mobil ization Models in Seven Successful Cases", Comparative Political Studies, 41 (1): 3-23. Available at: https://doi.org/10.1177/ 0010414006294168.

Jagers, Jan and Stefann Walgrave. 2007. "Populism as Political Communication Style: An Empirical Study of Political Parties' Discourse in Belgium”, European Journal of Political Research, 46 (3): 319-345. Available at: https://doi.org/10.1111/ j.1475-6765.2006.00690.x

Jansen, Robert S. 2011. "Populist Mobilization: A New Theoretical Approach to Populism”, Sociological Theory, 29 (2): 75-96. Available at: https://doi.org/ 10.1111/j.1467-9558.2011.01388.x.

Jost, John T., Federico Christopher M. and Jaime L. Napier. 2009. "Political Ideology: Its Structure, Functions, and Elective Affinities”, Annual Review of Psychology, 60: 307-337. Available at: https://doi.org/10.1146/annurev.psych.60.110707.163600. 
Kelsey, Darren. 2015. "Hero Mythology and Right-Wing Populism. A discourse-mythological case study of Nigel Farage in the Mail Online", Journalism Studies, 17 (8): 1-19.

Kriesi, Hanspeter y Takis S. Pappas (eds.). 2015. European Populism in the Shadow of the Great Recession. Colchester: ECPR Press.

Krouwel, Andre y Koen Abts. 2007. "Varieties of Euroscepticism and Populist Mobilization: Transforming Attitudes from Mild Euroscepticism to Harsh Eurocynicism", Acta Politica, 42 (2-3): 252-270. Available at: https://doi.org/10.1057/ palgrave.ap. 5500187

Laclau, Ernesto. 2005a. On Populist Reason. London: Verso.

Laclau, Ernesto. 2005b. "Populism: What's in a Name?", in Panizza, Francisco (ed.), Populism and the Mirror of Democracy. London: Verso.

Mastropaolo, Alfio (2005). La mucca pazza della democrazia. Nuove destre, populismo, antipolitica. Torino: Bollati Boringhieri.

Mazzoleni, Gianpietro. 2003. "The Media and the Growth of Neo-Populism in Contemporary Democracies", Mazzoleni Gianpietro, Julianne Stewart and Bruce Horsfield (eds.), The Media and Neo-populism: A Contemporary Comparative Analysis. Westport: Praeger Publisher.

Mazzoleni, Gianpietro and Winfred Schulz. 1999. "Mediatization of Politics: A Challenge for Democracy”, Political Communication, 16 (3): 247-261. Available at: https://doi.org/10.1080/105846099198613

Mény Yves and Yves Surel. 2000. Par le Peuple, pour le People. Paris: Libraire Arthème Fayard.

Minkenberg, Michael. 2001. "The Radical Right in Public Office: Agenda-setting and Policy Effects", West European Politics, 24 (4): 1-12. Available at: https://doi. org/10.1080/01402380108425462.

Mosca, Lorenzo. 2014. "The Five Star Movement: Exception or Vanguard in Europe?", The International Spectator, 49 (1): 36-52. Available at: https://doi.org/ 10.1080/03932729.2013.875821.

Mudde, Cas. 2004. "The Populist Zeitgeist”, Government and Opposition, 39 (4): 542-563. Available at: https://doi.org/10.1111/j.1477-7053.2004.00135.x

Mudde, Cas. 2007. Populist Radical Right Parties in Europe. Cambridge: Cambridge University Press. Available at: https://doi.org/10.1017/CBO9780511492037

Mudde, Cas. 2010. "The Populist Radical Right: A Pathological Normalcy", West European Politics, 33 (6): 1167-1186. Available at: https://doi.org/10.1080/0140 2382.2010.508901.

Mudde, Cas. 2013. "Three Decades of Populist Radical Right Parties in Western Europe: so What?", European Journal of Political Research, 52 (1): 1-19. Available at: https://doi.org/10.1111/j.1475-6765.2012.02065.x.

Mudde, Cas and Cristóbal R. Kaltwasser. 2013. "Exclusionary vs. Inclusionary Populism: Comparing Contemporary Europe and Latin America", Government and Opposition, 48 (2): 147-174. Available at: https://doi.org/10.1017/ gov.2012.11. 
Mudde, Cas and Cristóbal R. Kaltwasser. 2014. "Populism and Political Leadership", in T'Hart, Paul and Roderick A. W. Rhodes (eds.), The Oxford Handbook of Political Leadership. Oxford: Oxford University Press.

Mudde, Cas and Cristóbal R. Kaltwasser (eds.). 2012. Populism in Europe and the Americas. Cambridge: Cambridge University Press.

Müller, Jan-Werner. 2016. What is Populism? Philadelphia: University of Pennsylvania Press. Available at: https://doi.org/10.9783/9780812293784.

Müller-Rommel, Ferdinand. 1998. “The New Challengers: Greens and Right-wing Populist Parties in Western Europe”, European Review, 6 (2): 191-202. Available at: https://doi.org/10.1017/S1062798700003227.

Panizza, Francisco. 2005. "Introduction", in Francisco Panizza (ed.), Populism and the Mirror of Democracy. London: Verso.

Pappas, Takis S. 2012. Populism Emergent: A Framework for Analyzing its Contexts, Mechanics, and Outcomes. EUI Working Paper RSCAS 2012/01.

Pappas, Takis S. 2015. "Modern Populism: Research Advances, Conceptual and Methodological Pitfalls, and the Minimal Definition”. Oxford Research Encyclopedia of Politics. Available at: http://politics.oxfordre.com/view/10.1093/acrefore/9780190228637.001.0001/acrefore-9780190228637-e-17 [last accessed: 10th of June 2017].

Pappas, Takis S. 2016. “Distinguishing Liberal Democracy’s Challengers”, Journal of Democracy, 27 (4): 22-36. Available at: https://doi.org/10.1353/jod.2016.0059.

Roberts, K. M. (2006). "Populism, political conflict, and grass-roots organization in Latin America”, Comparative Politics, 38 (2), 127-148. Available at: https://doi. org/10.2307/20433986.

Rooduijn, Matthijs. 2014. "The Nucleus of Populism: In Search of the Lowest Common Denominator", Government and Opposition, 49 (4): 573 - 599 . Available at: https://doi.org/10.1017/gov.2013.30.

Rooduijn, Matthijs. 2015. "The Rise of the Populist Radical Eight in Western Europe", European View, 14 (1): 3-11. Available at: https://doi.org/10.1007/ s12290-015-0347-5.

Rooduijn, Matthijs and Tjitske Akkerman. 2015. "Article Flank attacks: Populism and left-right radicalism in Western Europe", Party Politics, 21 (4): 1-12.

Sartori, Giovanni. 2009. "Guidelines for Concept Analysis", in Collier, David and John Gerring (eds.), Concepts and Method in Social Science: The tradition of Giovanni Sartori. Oxon: Routledge.

Schori Liang, Christina. 2007. Europe for the Europeans The Foreign and Security Policy of the Populist Radical Right. Farnham: Asghate Press.

Schultz, Martin. 2015. Speech to the European Council by Martin Schulz President of the European Parliament, 19 of March 2015. Available at: http://www.europarl. europa.eu/meetdocs/2014_2019/documents/d-ru/dv/dru_20150324_02/ dru_20150324_02en.pdf [last accessed: 10th of June 2017].

Shields, James. 2007. The Extreme Right in France: From Pétain to Le Pen. London: Routledge. 
Stanley, Ben. 2008. "The Thin Ideology of populism”, Journal of Political Ideologies, 13 (1): 95-110.

Stavrakakis, Yannis and Giorgios Katsambekis. 2014. "Left-wing Populism in the European Periphery: the Case of SYRIZA", Journal of Political Ideologies, 19 (2): 119-142. Available at: https://doi.org/10.1080/13569317.2014.909266.

Taggart, Paul. 1995. "New Populist Parties in Western Europe", West European Politics, 18 (1): 34-51. Available at: https://doi.org/10.1080/01402389508425056.

Taggart, Paul. 2000. Populism. Buckingham: Open University Press.

Taggart, Paul. 2004. "Populism and Representative Politics in Contemporary Europe", Journal of Political Ideologies, 9 (3): 269-288. Available at: https://doi. org/10.1080/1356931042000263528

Taguieff, Pierre-André. 1995. "Political Science Confronts Populism: From a Conceptual Mirage to a Real Problem", Telos, 103: 9-43. Available at: https://doi. org/10.3817/0395103009.

Tronconi, Filippo. 2015. Beppe Grillo's Five Star Movement Organisation, Communication and Ideology. London: Ashgate press.

Urbinati, Nadia. 2013. "The Populist Phenomenon", Raisons Politiques, 51 (3): 137154. Available at: https://doi.org/10.3917/rai.051.0137

Urbinati, Nadia. 2014. Democracy Disfigured. Opinion, Truth, and the People. Cambridge: Harvard University Press. Available at: https://doi.org/10.4159/ harvard.9780674726383.

Verbeek, Bertjan, Andrej Zaslove and Davide Vittori. 2014. "Fours Ways for Populists to Affect Foreign Policy", paper presented at the ECPR General Conference, 3-6 September, Glasgow.

Weyland, Kurt. 2001. "Clarifying a Contested Concept: Populism in the Study of Latin American Politics", Comparative Politics, 34 (1): 1-22. Available at: https:// doi.org/10.2307/422412.

Weyland, Kurt. 2013. "Populism and Social Policy in Latin America", in Carlos de la Torre, Carlos and Cynthia J. Arnson (eds.), Latin American Populism in the Twenty-First Century. Baltimore and Washington: The Johns Hopkins University and the Woodrow Wilson Center Press.

Wiles, Peter. 1969. "A Syndrome, Not a Doctrine: Some Elementary Theses on Populism”, in Ionescu, Ghita y Ernest Gellner (eds.), Populism: Its Meaning and National Characteristics. New York: Macmillan.

Zakaria, Fareed. 1997. "The Rise of Illiberal Democracy", Foreign Affairs, 76 (6): 22-43. Available at: https://doi.org/10.2307/20048274.

Zaslove, Andrej. 2008. "Here to Stay? Populism as a New Party Type", European Review, 16 (3): 319-336. Available at: https://doi.org/10.1017/S1062798708000288.

Presentado para evaluación: 17 de marzo de 2017.

Aceptado para publicación: 25 de junio de 2017. 


\section{DAVIDE VITTORI}

dvittori@luiss.it

$\mathrm{PhD}$ student at LUISS University. His main research interests are party politics, movement parties, party organisation and populism. His last publications are: "Cartelization and party change in social democracies: a comparative perspective on the Parti Socialiste (PS), Partido Socialista Obrero Español (PSOE), and Partito Democratico (PD)" in the Italian Political Science Review, and "Podemos and the Five-star Movement: populist, nationalist or what?" in Contemporary Italian Politics. 